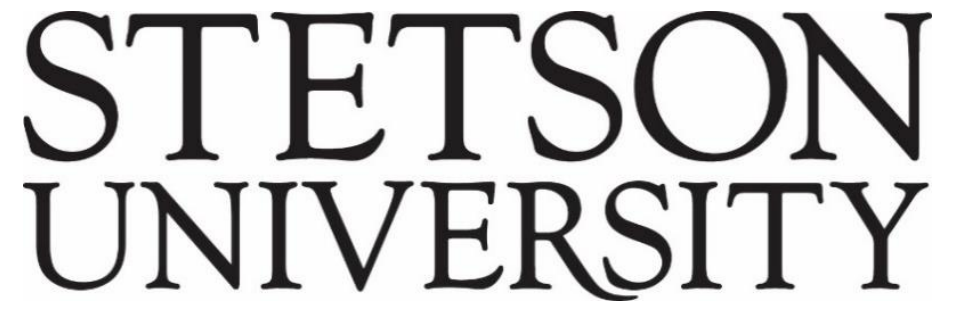

Voices of Reform: Educational Research to Inform and Reform

Volume 2・Issue $1 \bullet$ Article 6

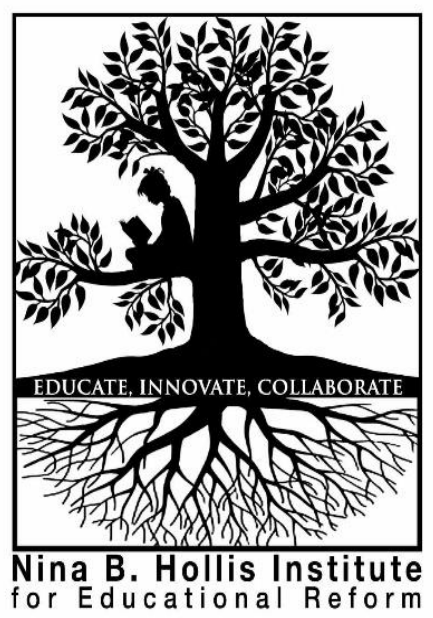

September 2019

\title{
Reinventing the Mission: The Vital Role of Academic Support in the Higher Education Accountability Era
}

Joseph L. Huston

Seminole State College of Florida

Follow this and additional works at: http://www.voicesofreform.com

Recommended Citation

Huston, J. (2019). Reinventing the mission: The vital role of academic support in the higher education accountability era. Voices of Reform, 2(1), 87-95. Retrieved from https://www.voicesofreform.com/article/10633reinventing-the-mission-the-vital-role-of-academic-support-in-the-higher-education-accountability-era doi: $10.32623 / 2.00008$

http://dx.doi.org/10.32623/2.00008

Revisions

Submission date: November $21^{\text {st }}, 2018$

$1^{\text {st }}$ Revision: January $29^{\text {th }}, 2019$

Acceptance: March 12 ${ }^{\text {th }}, 2019$

Publication date: September 30 2019 


\title{
Reinventing the Mission: The Vital Role of Academic Support in the Higher Education Accountability Era
}

\author{
Joseph L. Huston ${ }^{1}$ \\ ${ }^{1}$ Director of Academic Success \\ Seminole State College of Florida, United States \\ hustonj@seminolestate.edu
}

\begin{abstract}
Historically, academic support departments have played a relatively passive role in our colleges and universities. Providing traditional, out-of-class support services such as tutoring, supplemental instruction, and skills workshops, these functions have commonly operated in detachment from the course environment. Faculty, particularly at two-year colleges, frequently encounter students with vastly different academic backgrounds and social experiences all within a single classroom. Within these classroom environments, cultural constructs such as the expectation of student selfdetermination and student accountability for performance collide with the varied realities of students' prior educational access and opportunities for accumulating the requisite knowledge, skills, and experiences conducive for success in higher education. As a landscape of elevated accountability has emerged for higher education, institutional administration, department leaders, and faculty are all feeling pressure for student success (Austin \& Sorcinelli, 2013). The environment is ideal for academic support units to explore the possibilities for integrating academic support services proactively into programs and courses. Working collaboratively with faculty to develop integrated academic support can create pathways towards the inclusive engagement of all students while equalizing opportunities for learning and success at the collegiate level.
\end{abstract}

\section{Keywords}

higher education, academic success, student services

\section{The Landscape of Accountability}

My career in education began as a high school math teacher in the No Child Left Behind era. Accountability for students passing my Algebra 1 course landed squarely on my shoulders. I can vividly recall the details of every wrinkle on the face of the school Principal as his eyes squinted, 
scouring my class grade reports from behind his desk at the end of the first term. I sat uncomfortably squirming in my chair, waiting for the inevitable dubious glance upward. "Why, Mr. Huston, are more than $30 \%$ of your students scoring below a C?"

In hindsight, I can report that my students averaged a bit better than $90 \%$ learning gains in my years teaching public high school mathematics, but as I transitioned into a career in higher education, I couldn't help but feel that the environment of accountability would soon follow. In the wake of the K-12 accountability movement, the Spellings Commission report of 2006 ushered in a renewed focus on public higher education outcomes. Unlike my K-12 experiences, higher education accountability pressures would be enacted largely through the implementation of performance-based funding models designed to measure institutional and student performance outcomes (Burke, 2002; Dougherty et al., 2016; Ewell, 2009). Nonetheless, the expectation for student performance improvements within programs and individual courses has inevitably worked its way through our colleges and universities to the individual course level all the same.

As colleges and universities examine their own undergraduate academic outcomes, it is a common finding that specific general education courses tend to behave as gatekeeper courses (Roksa, Jenkins, Jaggars, Zeidenberg, \& Cho, 2009). As described by the John N. Gardner Institute, these gateway courses draw large enrollments as general education requirements, but frequently result in low course success rates with DFWI (course grades of D, F, withdrawal, or incomplete) rates of $30 \%$ or more (Koch \& Pistilli, 2015). Once again, we begin to hear challenges to the value of a college degree, this time not only predicated upon concerns over the time and monetary commitment of students and their families, but also for the efficient and effective use of public funds as measured by student performance outcomes (Kelchen, 2018). Not surprisingly, calls for enhanced instructional effectiveness in undergraduate education have been pronounced over the past two decades, largely citing student performance outcomes as driving factors (Carnegie Foundation for the Advancement of Teaching, 1998; Olitsky, 2014).

Pushing back against these calls for elevated student performance, faculty commonly report that the under-preparedness of incoming students represents a significant barrier to delivering effective undergraduate instruction (Michael, 2007; Sorcinelli, Austin, Eddy, \& Beach, 2006). One recent estimate gauged that nearly two-thirds of incoming community college students were academically underprepared for the rigors of college coursework (Bailey \& Jaggars, 2016). Students characterized as "underprepared" often have expectations regarding time commitments and outof-class workloads that differ substantially from the expectations of the faculty (Sorcinelli, et al., 2006). Analogously, research has recently indicated that our institutions are equally underprepared to support faculty in adjusting course structures or teaching strategies for students who may require additional support in college-level coursework (Shankle, 2016). These complementary observations, juxtaposed against a backdrop of elevated pressure for student performance outcomes, present an open door to academic support departments. Now is the time to reinvent the mission of our academic support departments away from passive operations and demonstrate their vital role within higher education institutions. 


\section{Personality and Partnerships}

When I accepted the position as Director of the Academic Success Center (ASC) and the Student Transition and Achievement Resources (STAR) Center at Seminole State College of Florida, I think it is fair to say that I inherited a fairly traditional operation. The department, funded largely through a student activity and service fee, provided on-campus drop-in tutoring at each of the college's four campuses. Situated as an academic affairs unit at a public, two-year degree granting institution, the available services were largely limited to on-campus tutoring for general education math, science, and English courses, though writing support spanned the curriculum. Under the operating model that was in place, students who voluntarily chose to avail themselves of the free tutoring services typically represented about ten percent of the nearly 20,000 students enrolled each semester. Entering the new role, I brought with me a vision for what a $21^{\text {st }}$ century academic support program could develop into and the goals it could potentially achieve. That vision is for academic support operations to function in an entirely integrated way with our academic programs, not detached from our courses and placed in the basement of some peripheral building barely hanging onto a campus address. Rather, academic support operations should be intimately integrated into the structure of our courses and our programs. Academic support personnel should work cooperatively and collaboratively with faculty and academic administration to address the specific challenges that students encounter within particular courses so that they can be strategically projected into the pathway of students, as opposed to waiting for challenged students to walk into our spaces.

In my view, an academic support department is uniquely situated at the confluence of three strong, and occasionally misaligned forces: institutional and external pressures for elevated academic outcomes, student needs for engaged learning opportunities and interventions, and the faculty imperative for preserved academic rigor and integrity. Described this way, it sounds like a precarious balance, but I view it as a great position from which to make a substantial contribution to our students, faculty, and institution. Yet, navigating such a landscape requires some assistance if we are to be integrated successfully.

At Seminole State College, it is my vision that our academic support departments be viewed as the college's "partnership departments." We have forged strategic partnerships with units all across the college. Institutional Research helps us to identify programs and courses that could benefit from intervention. Our grants department and foundation are partners helping to seek out funding opportunities. Joint ventures with the library, disability support services, our faculty center for teaching and learning, and student life, all contribute to our ability to gain further interactions with students and faculty. In return, our interventions contributed to elevated student engagement and success within many programs. But the key to our success over the past few years has been developing and cultivating essential partnerships with our faculty, Deans, and academic leadership.

This has not been an easy process. Our many partnerships with faculty have taken shape over several years, often starting with just a few faculty who are amenable to collaborating and testing out an intervention strategy on a "pilot-basis." The grass-roots nature of these partnership efforts has been essential to allowing authentic relationships to emerge, predicated on trust and past 
accomplishments. These burgeoning relationships with faculty allow for our academic support operations to be positioned more strategically to propose further course and program integration. Beginning slowly and working collaboratively with faculty to help develop our intervention initiatives has been the necessary foundational work of "getting to yes" when it comes to growing our initiatives and seeking broader faculty participation.

\section{Academic Detectives}

Developing an intervention strategy typically begins with some expression of need from a faculty member, a Dean, or perhaps a suggestion from Institutional Research. No matter how a particular course or program has been identified as a possible locus for developing a support strategy, there are a few general assumptions that I hold when beginning to explore possibilities:

- Faculty are the content area experts and must be included in the conversation.

- Faculty own their courses; our role is to support their efforts and propose options for enhancing student learning and performance through interventions and strategies.

- Our work must focus on enhancing student learning and academic performance while maintaining the intended rigor of the course.

- Financial resources are probably thin and so we must seek efficiency while planning for effectiveness.

With these ideas in mind, it is critical to develop a solid understanding of a course structure, faculty expectations for student performance, and how students are currently experiencing the course before we propose a support initiative. In my experiences, the best way to accomplish effective communication and productive integration of academic support with faculty is to leverage a distributed leadership model (Sloan, 2013). In this model, ownership is shared among multiple constituents and decision making is ultimately left to the faculty. Typically, I seek to begin a conversation with the Dean or Department Chair regarding the particular course and the department's goals. A panel or focus group of faculty are then invited to engage in the conversation. Faculty are encouraged to share their observations of student performance and to explore their perceptions of why students are facing challenges in the course. Finally, reviewing course syllabi for further details regarding course structure and content, assignments, grade structure, and expressed faculty expectations can be very enlightening. Occasionally it may be generative to survey or speak with a few students about their experiences as well. In reality no single support strategy can serve as a panacea. All of these considerations are important to ensure that the proposed support initiatives will actually align with the course and address the concerns and challenges faced by students and faculty.

\section{Integrating Academic Support into the Course Environment}

As I have described it, our implementation process represents a distributed leadership model for engaging faculty and institutional administration in the development of our academic support interventions. When a college-wide course success rate is observed to be trending lower or has maintained a relatively low level over a period of time, we begin to investigate how integrated academic support might be able to provide assistance. Engaging in a shared development process 
over the past few years has resulted in the establishment of partnerships that have exceeded my expectations. Collaboratively, we have worked with faculty and institutional leadership to integrate academic support into our courses through a number of innovative solutions, a few of which I will showcase here:

\section{Biology Mock Lab}

At many colleges and universities, student success rates in general education science courses, such as general biology, tend to be low. After exploring the course structure and discussing student performance with the department chair, faculty, and students, we identified the course's two lab practical exams to be a source of student challenge. Very few students enrolled in the course had ever experienced a lab practical in their prior schooling. The lab practical exams combined for a sizeable portion of the course grade and faculty indicated that student performance was historically below expectations. The resulting support strategy was for the Academic Success Center to host a 'Mock Lab' experience, developed in cooperation with the faculty, to be made available to all students in the two weeks prior to the actual lab practical exams. We implemented the initiative through a pilot effort, initially working with three faculty, and have subsequently scaled the initiative to full implementation. In our most recent administration of the biology mock lab, over 330 students (nearly half of all those enrolled) participated in the optional event. The result was an $84 \%$ course success rate among participants. An additional benefit of this initiative is that it occurred within our tutoring centers during normal operating hours, thus requiring zero additional labor expenditure and introduced our support services to many new students who would not otherwise have stepped through our doors.

\section{MathChat Live}

Like most academic support departments, we would be challenged to provide comprehensive online tutoring support to our entire student body; we simply lack the bandwidth of human and financial capital to provide such comprehensive coverage. We leveraged a third-party vendor to provide this type of broad coverage around the clock. However, we also delivered specialized online tutoring support functions in-house in order to provide support that is more directly applicable to the specific needs of our students. Utilizing a web-conferencing platform, our tutors provided online group reviews and tutorial sessions that were customized to individual courses and instructors. For student participation to flourish, these online sessions were delivered on the same days and times each week consistently throughout the semester. Through partnerships with faculty, our MathChat Live sessions were tailored to the exact needs of the students enrolled in courses such as algebra, statistics, and trigonometry. Each session reviewed current topics and concepts, while providing for Q\&A time at the end. Student participation began slowly but grew as awareness increased. Attendance varied at each session, though typically attended by three to eight students, rising to as many as many as 25 students during final exam reviews. Again, this initiative captured new, additional student participation with our services. Utilizing student workers, a fixed cost of less than $\$ 20$ per online tutoring session represents an efficient ratio of labor expense to student interaction when considering the one-to-many paradigm of the sessions. 


\section{Embedded Tutoring}

Embedded tutoring has been one option that we have leveraged to increase our impact and bolster student participation. Rather than waiting for a student who is experiencing challenges to find our support services, we take the show on the road. By partnering with faculty to integrate a tutor into the actual course, student participation becomes a given. The tutor in the classroom can help facilitate classwork and activities alongside the instructor. The added benefit is that the faculty member can help direct the embedded tutor to interact with those individual students who need his or her assistance the most. From a budget standpoint, this is also a winning strategy in that a single labor hour can impact a dozen or more students within a single class period. We have also found that the relationships that develop between the tutor and the students in the classroom often translates into additional student visits to our tutoring centers. We have leveraged embedded tutors across a number of disciplines including accounting, fine and performing arts, mathematics, business modeling and simulation, legal studies, and biological and physical sciences, all with increased course success rates. By leveraging student workers, this intervention is also quite cost effective, averaging approximately $\$ 250$ per section per semester.

\section{Moving Forward to Reframe the Mission}

Our process represents a productive pathway for honoring the tradition of shared governance while respecting the imperative of enhanced outcomes associated with an environment of elevated accountability. By integrating our academic support functions with the college's academic and service departments, we have enabled the college community to engage in respectful, productive conversations oriented to developing integrated academic support initiatives. The more integrated with our faculty endeavors our academic support operations become, the more effective and applicable they will become for our students. Addressing student academic behaviors, skills, and prior knowledge, situated within the course structure and contextualized by students' own individual past experiences ensures that our work constructively promotes enhanced student performance and assists faculty in their work. These partnerships also contribute to the preservation of faculty intended rigor of their courses while simultaneously providing the support assistance that individual students need to achieve success. That is a mission that I think we can all support.

\section{References}

Austin, A. E., \& Sorcinelli, M. D. (2013). The future of faculty development: Where are we going? New Directions for Teaching and Learning, 2013(133), 85-97. doi: 10.1002/t1.20048

Bailey, T., \& Jaggars, S. S. (2016). When college students start behind. The Century Foundation. Retrieved from http://hdl.handle.net/10919/83634

Burke, J. C. (2002). Funding public colleges and universities for performance. Albany, NY: Rockefeller Institute Press.

Carnegie Foundation for the Advancement of Teaching. (1998). Reinventing undergraduate education: A blueprint for America's research universities. Princeton, NJ: Boyer Commission on Educating Undergraduates in the Research University.

Dougherty, K. J., Jones, S. M., Lahr, H., Natow, R. S., Pheatt, L., \& Reddy, V. (2016). Performance funding for higher education. Baltimore, MD: Johns Hopkins University Press. 
Ewell, P. T. (2009). Assessment, accountability, and improvement: Revisiting the tension (NILOA Occasional Paper No. 1). Urbana, IL: University of Ilinois and Indiana University, national Institute of Learning Outcomes Assessment. Retrieved from http://www.learningoutcomeassessment.org/documents/PeterEwell 005.pdf

Kelchen, R. (2018). Higher education accountability. Baltimore, MD: Johns Hopkins University Press.

Koch, D., \& Pistilli, M. (2015). Analytics and gateway courses: Understanding and overcoming roadblocks to college completion. Retrieved from https://www.insidehighered.com/sites/default/server_files/files/Analytics\%20and\%20Gateway\%20Courses \%20PPt.pdf

Michael, J. (2007). Faculty perceptions about barriers to active learning. College Teaching, 55(2), 42-47. https://doi.org/10.3200/CTCH.55.2.42-47

Olitsky, N. H. (2014). How do academic achievement and gender affect the earnings of STEM majors? A propensity score matching approach. Research in Higher Education, 55(3), 245-271. doi: 10.1007/s11162-013-9310-y

Roksa, J., Jenkins, D., Jaggars, S. S., Zeidenberg, M., \& Cho, S. W. (2009). Strategies for promoting gatekeeper course success among students needing remediation: Research report for the Virginia Community College System. New York, NY: Teachers College, Community College Research Center, Columbia University.

Shankle, C. A. (2016). Faculty perspectives on underprepared students. Journal of Psychology, 4(2), 37-58.

Sloan, T. (2013). Distributed leadership and organization change: Implementation of a teaching performance measure. The New Educator, 9(1), 29-53. doi: 10.1080/1547688X.2013.751313

Sorcinelli, M. D., Austin, A. E., Eddy, P. L., Beach, A. L. (2006). Creating the future of faculty development: Learning from the past, understanding the present. Bolton, MA: Anker.

\section{Appendix A}

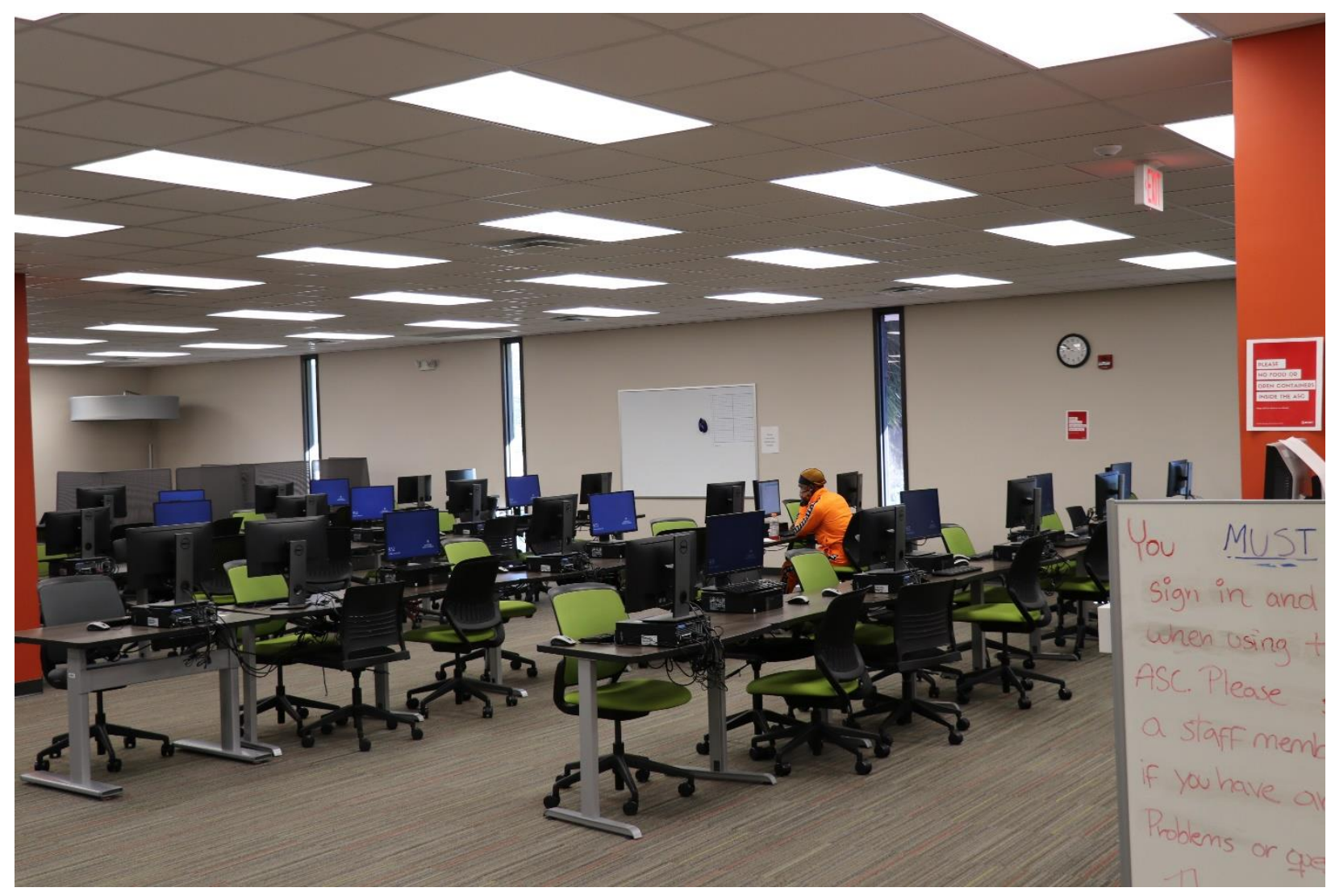

Figure 1: Seminole State's Academic Success Center, Sanford Campus. 
Huston: Reinventing the mission: The vital role of academic support in the higher education accountability era

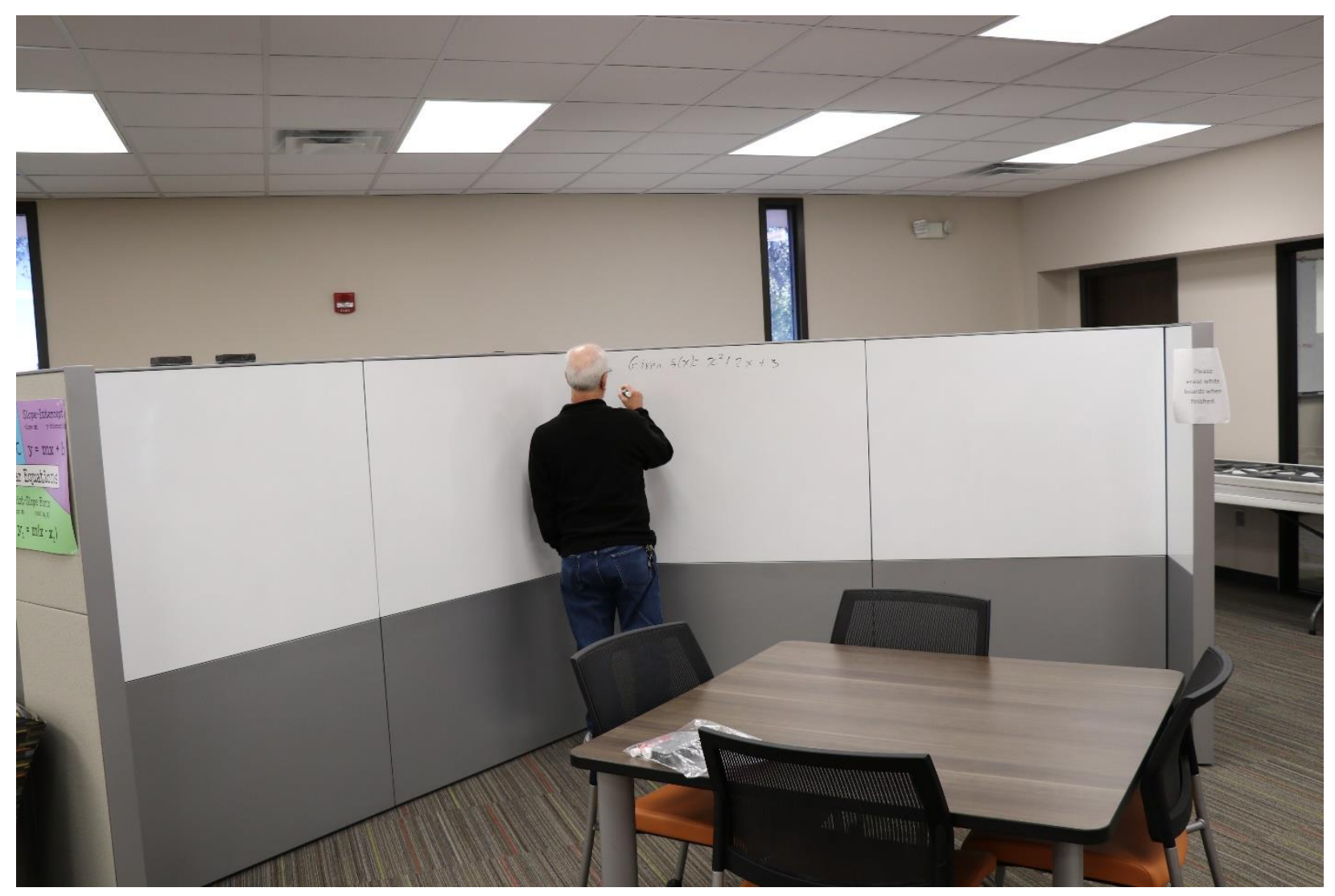

Figure 2: Embedded tutors assisting students in college mathematics. 